\title{
Polish ports in the period of transformation
}

\author{
by TADEUSZ PALMOWSKI \\ Department of Economic Geography, University of Gdańsk, Poland
}

\begin{abstract}
Polish ports are located peripherally with respect to main shipping routes on the Baltic and the North Sea. In order to develop the hinterland of the ports, in market conditions, the development of transport north-south connections is of fundamental importance. Transport lines in the east-west directions adversely affect port economy.
\end{abstract}

\section{Geographical considerations}

Ports on the Baltic Sea are linked together by a number of road, rail and ferry routes. There is an increasing amount of shipping between them and North Sea and other ports. Although intercontinental container transport goes through the most important ports of the North Sea, ships carrying bulk and general cargoes are directly connected with the Baltic ports and overseas countries. The most important Baltic ports- are connected with the hinterland by a road and railway network, while inland waterways are of less importance (only in Germany and Finland is that kind of transport well developed). Because of Poland's geographical location, the main transport lines in the east-west and north-south directions run through its territory. These lines offer a great opportunity for Poland but the necessary transport investments must be completed first (figure 1).

The position of Polish ports in the competitive transport market is determined by its peripheral location with reference to both the main shipping routes on the Baltic and North Sea and important industrial centres in Europe, so the Polish ports cannot pretend to be distribution and handling centres on a European scale. Such centres form the bases for navigation, and increasing concentration of overseas turnover has limited the number of such ports to a few basic, e.g. Hamburg, Bremen and Antwerp. The Baltic ports accommodated regional and feeder services.

The centrally administered system in Poland during the period of 'real socialism' created large monopolistic national enterprises possessing the exclusive rights to provide certain services. This policy resulted in preferences for extensive directions of functioning and development, which deepened the technological and organizational gap between Polish and West European ports. In the new Polish economy, governed by the principle of competition, the process of restructuring ports splits their activity into business and administration of ports' areas and the operational activity, introducing privatization and demonopolization. Economy and administration determine the facilities of Polish ports nowadays. Both domestic and transit facilities have changed their character.

Szczecin-Świnoujście complex, located at the European Union border, at the mouth of the River Odra, is one of the biggest ports on the Baltic Sea with its trans-shipping tonnage of 28 million tons. Ships to 70000 DWT are regularly serviced here. In 1995,15-6 million tons of cargo were handled (figure 2). The advantage of Szczecin-Świnoujście port is the geographical location not only on the north-south axis of Europe, i.e. on the axis of Scandinavian and Central European countries, but with respect to industrial centres in Poland (Silesia-Śląsk) and also in other countries providing a natural hinterland for the 


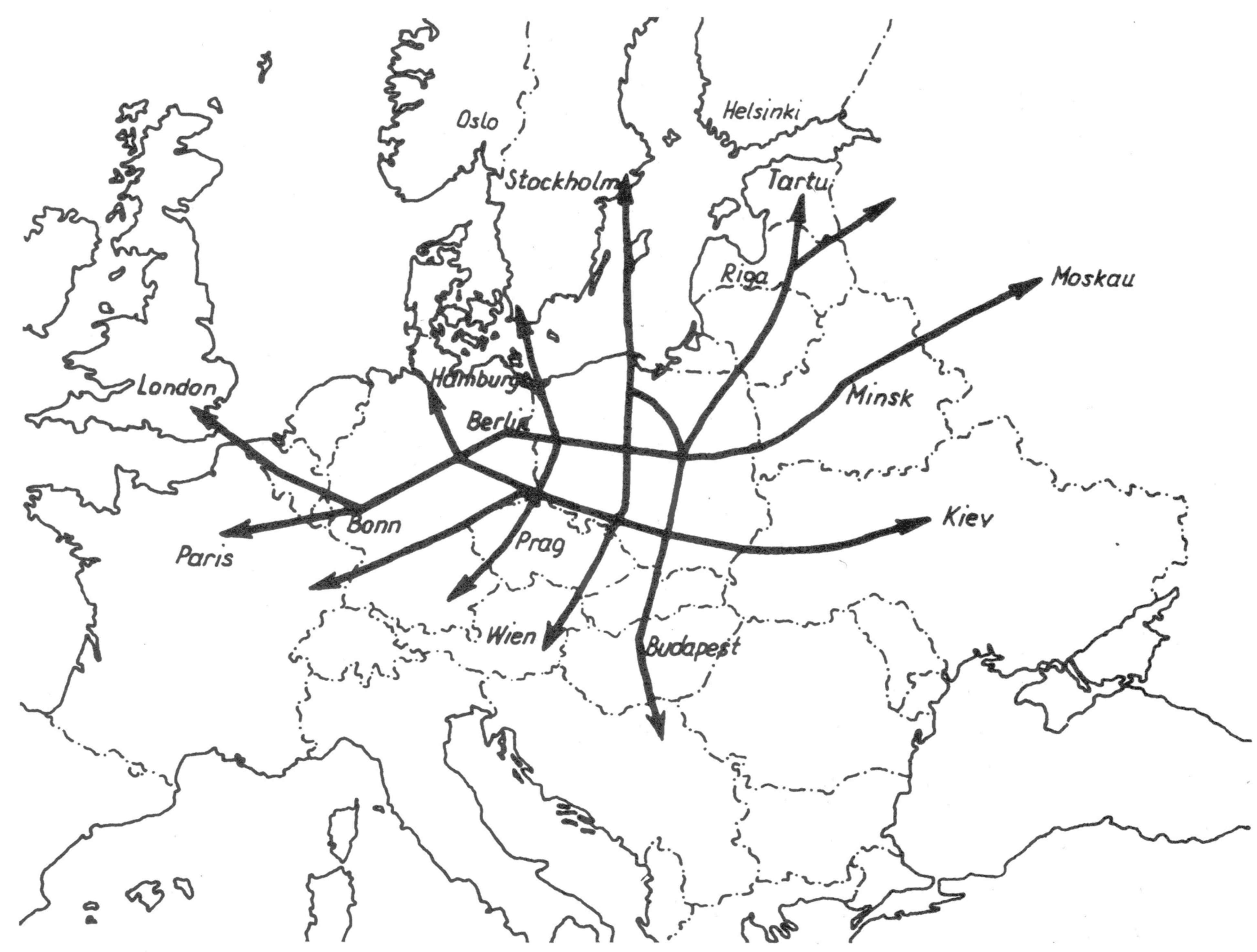

Figure 1. East-west and north-south transport lanes. [Source: T. Basiewicz, 1993.]

port, such as the Czech Republic and Slovakia, and the eastern part of Germany (mainly the frontier areas of Brandenburg and Meklenburg-Pomerania). There is an opportunity for the Szczecin-Swinoujście complex to undergo futher development due to the parallel inland communication system.

The advantageous conditions open perspectives for Szczecin-Swinoujście to become a transit port. In 1995, 2-1 million tons of transit cargo was handled here. Germany came first, as one of the transit partners, with 745000 tons of handled iron ore and building materials, followed by the Czech Republic and Slovakia. Projections indicate stability in this respect in future years. An increasing number of German enterprises send their goods via Szczecin-Swinoujście where good connections exist by land and waterways with Berlin and other important industrial centres of eastern and southern regions (lands).

The density of the existing railway network servicing ports, together with a big handling capacity, are features characteristic of the complex which indicate that it is not lagging behind European parameters. The Odra trunk-line E-59, Świnoujście-SzczecinKostrzyń-Wrocław-Chałupki, is an excellent link with Polish and foreign hinterland (figure 3). In 1994 railways carried 87-3\% of bulk and dry cargoes shipped through the Szczecin-Swinoujście complex. In second place came inland waterways, with $11-4 \%$ of handled goods at the Odra river ports. Conditions on the Odra River allow for effective use of the waterway, mainly for transport to Berlin and by European inland waterways to some West European countries. Participation of motor transport is not large, about 1-3\% (1994), as a result of the lack of a modern road network connecting ports with public roads, and the parameters of the existing roads which do not fully comply with contemporary requirements. 




Figure 2. Range of operational base of Polish ports. [Source: T. Szczepaniak, 1996.]

\section{Port facilities}

Thanks to the World Bank loans, the modernization of the Szczecin-Świnoujście ship channel is planned, as well as the rebuilding of some container berths and construction of an overfly to the port. The developing strategy of the Odra river ports indicates that Świnoujście will be the port for bulk cargo, whereas in Szczecin bulk cargo quays will be substituted by universal ones. Modern general cargo potential adjusted to serve ro-ro, lo-1o ships by modernizing the existing container base and building a multifunctional terminal at Ostrów Grabski hold priority in future plans.

The port of Gdańsk, with its 1000-year-long tradition, is situated at the mouth of the Vistula River, and only $15 \mathrm{~km}$ from it, while 75 years ago the port of Gdynia came into being. The former is the biggest available on the Baltic Sea to serve ships of the 'Baltimax' class, the largest vessels to go through the Danish Straits. The port consists of the inner harbour, a traditional one located at the mouth of the Vistula River, and the outer port, called Port Północny (Northern Port) built in the 1970s and protruding into the sea with a modern, deep fairway. In 1994, 22 million tons of freight was handled here. The majority of regular cargo reaches the harbour via railways with only $1 \%$ transported by inland waterways, but to improve the communication access to the port, the transeuropean northsouth arterial highway is to be built.

The port of Gdańsk is east oriented in its strategic plan. Connecting the port by broad-gauge railway with Kaliningrad district and Belorus, as well as building a grainfodder terminal with store-pits for 100000 tons each, will allow for the handling of 3 million tons of wheat, corn and soya from the U.S.A. and Canada, to be farther transported to the Commonwealth of Independent States (CIS). Additionally, plans for 


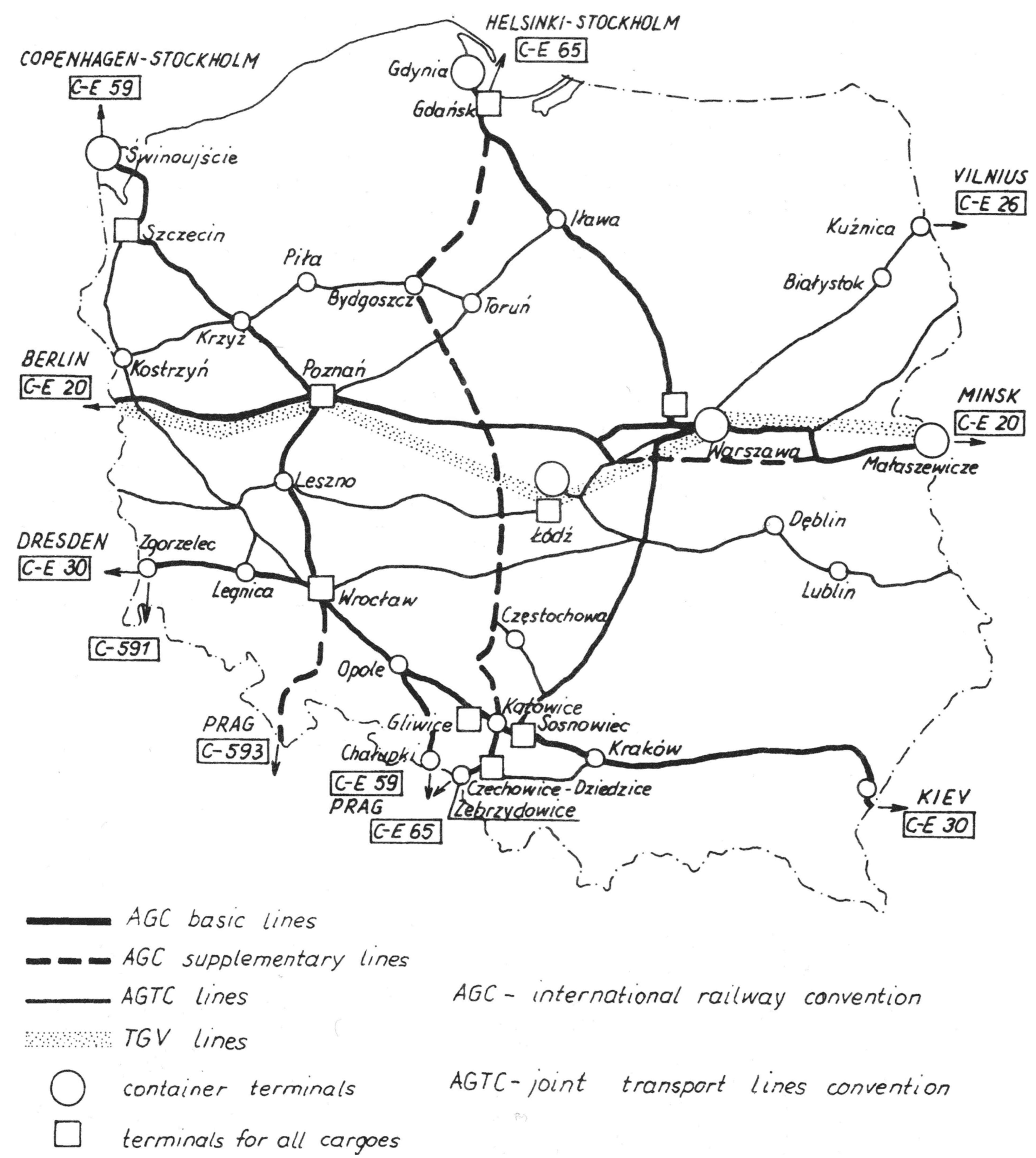

Figure 3. AGC and AGTC railways in Poland. [Source: J. Kołodziejski, 1995.]

the construction of terminals for liquid chemicals and ro-ro ships as well as a new ferry base are projected.

The port of Gdynia is a universal one, specializing in general cargo, mainly containers and grain. The port's turnover surpassed 8 million tons, with a trans-shipping capacity of 15 million tons. Restructuring of the port was completed in 1995 and led to splitting the enterprise into several small independent subsidiary companies operating under the joint name MPH Gdynia S.A. (Maritime Commercial Port in Gdynia: Joint Stock Company). Annually it serves approximately 50\% of total general cargoes passing through Polish ports. In the structure of the port's turnover, general cargo, including container general cargo, takes about $40 \%$. At present, its annual trans-shipping capacity is $170000 \mathrm{TEU}$ (in 1994 reloaded 122.1). In 1994, ten regular shipping lines were in service. Since 1 
December 1994 a container train has been running twice a week to the terminals in Sosnowiec and Łódź, and in February 1995 a regular container line was opened to Warsaw, then Wrocław and Małaszewicze. There are plans to connect Gdynia with Budapest, Vienna, Verona and Udina in Italy.

The Baltic Container Terminal includes the ferry base loacated within the area. The ferry terminal handles $25 \%$ of passenger ferry transport and $10 \%$ of ferry-shipped goods. Because the previous facilities were of a temporary character, a project was set up to build a new big modern ferry base located in the western part of the port. The new terminal will be the beginning of a transeuropean north-south highway and a part of the investment called the Baltic Ferry Bridge, with the other end of the bridge in Karlskrona, Sweden.

\section{Road connections}

Conditions necessary for proper port operation require appropriate transport connections with domestic and foreign (in case of transit) bases. Serious delays are observed due to the Polish road network, especially in terms of ready access to the ports and highways. It is essential for the development of motor transport, including joint carriage, to upgrade the existing road network, and to build motorways and highways. In 1993, the project of building motorways was set up in Poland. Successively, the following motorways will be constructed (figure 4).

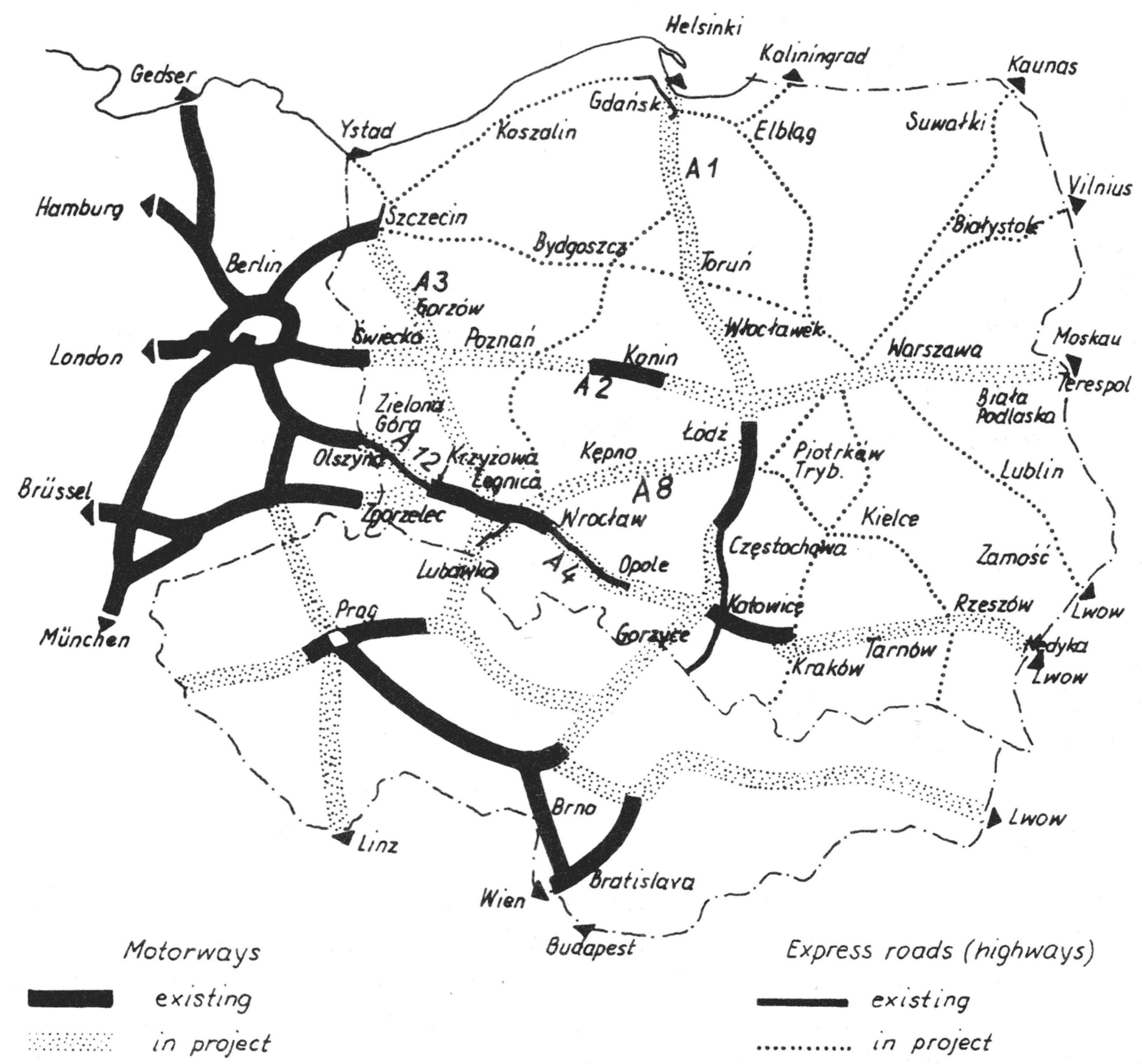

Figure 4. Motorways planned in Poland. [Source: W. Grzywacz et al., 1994.] 
(a) Gdańsk-Toruń-Częstochowa-Katowice-Gorzyce (A-1)

(b) Swiecko-Poznań-Warszawa-Terespol (A-2)

(c) Zgorzelec-Wrocław-Katowice-Kraków-Medyka (A-4), with the branch towards Berlin via Olszyna-Krzyżowa. (A-12)

These will be followed by two others:

(d) Szczecin-Gorzów-Zielona Góra-Legnica-Lubawka (A-3)

(e) Wrocław-Łódź (A-8)

The total length of the road network consisting of the four motorways A-1, A-2, A-4 and A-12 amounts to $1961 \mathrm{~km}$. The total length of motorways in Poland is to reach $2600 \mathrm{~km}$ and highways $3900 \mathrm{~km}$.

The order of constructing morotways is controversial. The neighbouring countries and western capital prefer to build parallel connections in the east-west direction. From the Polish point of view, with its maritime economy and interest in tourism, the priority is seen to be for the A-1 motorway, which is a part of a north-east line (Transeuropean Motorway, TEM). The concept of the TEM was brought up in Poland in the 1960s and approved by the European Economic Committee of the U.N. Ten countries came to an agreement under the protectorate of the U.N., and the A-1 line is to link Scandinavia with southern Europe and the near east by ferry lines (figure 5).

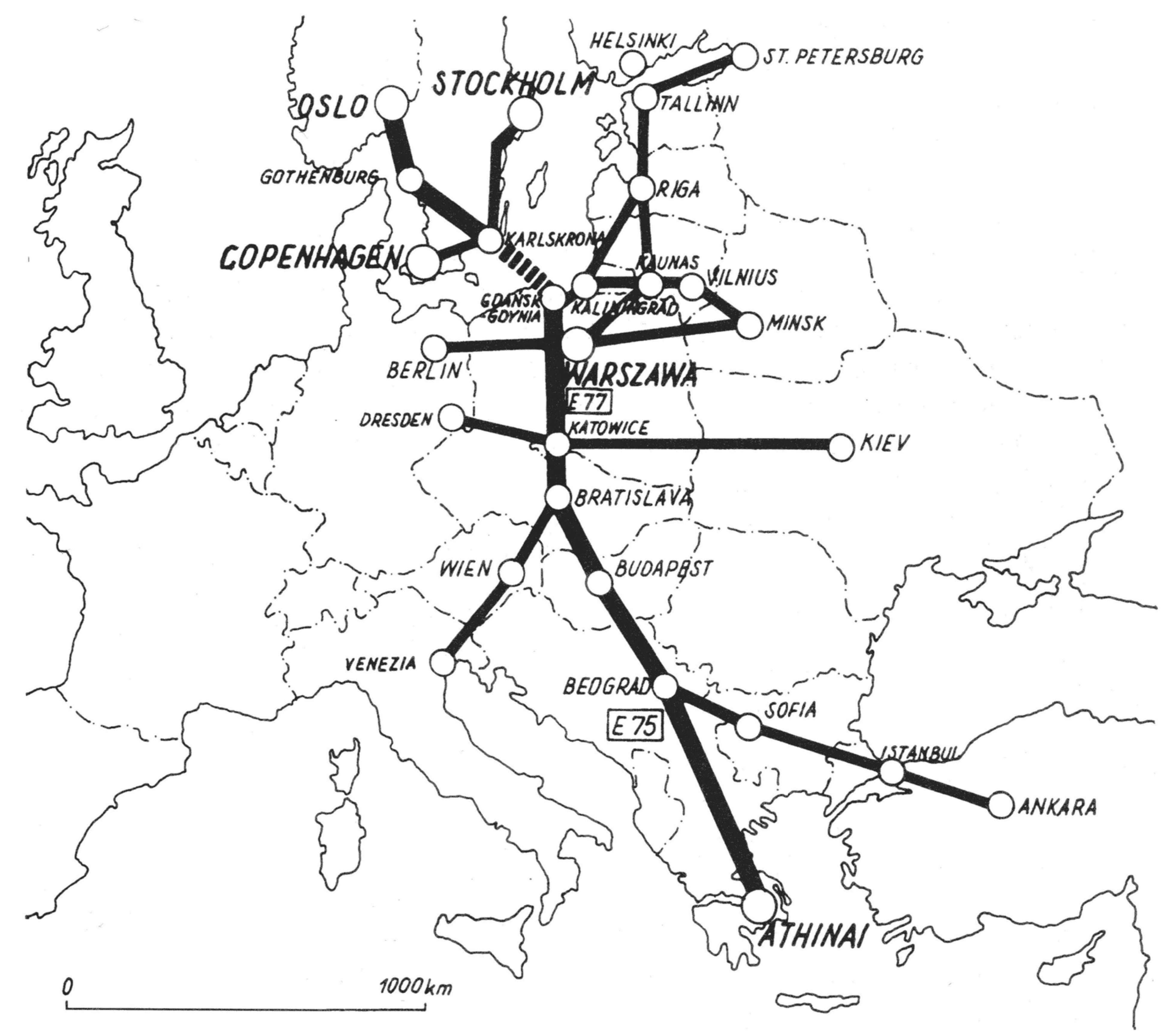

Figure 5. North-south transport axis. Motorway A-1. [Source: Gazeta Portowa, June 1995.] 
Because of the route benefits of the A-1 line over the E-55 route (Berlin-DresdenPrague-Brno), Scandinavian countries are very much interested in the progress of the $560 \mathrm{~km}$-long Polish section. On Polish territory, the TEM is going to be used for domestic loads, Polish foreign trade, and transit transportation. Furthermore, the motorway will encourage Polish and international tourism. Of the $10000 \mathrm{~km}, 4000 \mathrm{~km}$ have already been completed, $3000 \mathrm{~km}$ are under construction, and the remaining $3000 \mathrm{~km}$ are still in the designing phase.

An eastern branch of the TEM will link Gdańsk with Elbląg, Kaliningrad and St Petersburg. This branch, expanding the area covered, can positively affect the turnovers of the Gdańsk and Gdynia ports. To some extent, the planned line connecting KaliningradElbląg-Szczecin-Lubeka (via Hanseatica) and (via Baltica) from Tallin-Riga-Kaunas to Warsaw could be a threat for Polish maritime economy.

\section{Rail links}

The Polish railway network is among the oldest in Europe. Technical parameters must be adapted to the international requirements of the AGC (1985) and AGTC (1991), which have been signed by Poland. As the result of modernization of the railways qualified for AGTC, the complete journey of block trains will be covered in 12 hours, whereas trains going between ports and land terminals for import and export service will cover the distance in 7-10 hours. Gdańsk-Gdynia and Szczecin-Swinoujście ports have two pairs of arterial roads each in the meridian directions, connecting domestic and transit hinterlands.

From the Polish ports and their hinterlands' points of view, the modernization of domestic lines E-59 and E-65 is essential. This upgrading is included in the programme called TER (Trans European Railway), connecting Swinoujście-Chałupki and GdyniaZebrzydowice (figure 3). E-65 is a priority in this programme because it provides great potential for transport between Scandinavia and south Europe.

In the 1970s some sections of the Central Trunk Line were constructed on the central axis of the railway network in the north-south direction, adapted for speeds of $160 \mathrm{~km}$ per hour. The trunk line was built from the outset to allow speeds of between 200 and $250 \mathrm{~km}$ per hour. Modernization of E-65 must not only improve communication between the agglomerations of Gdańsk, Warszawa, Katowice and Krakow but, together with ferry lines linking Gdynia with Karlskrona and Gdańsk with Helsinki and Okselosund, become a flexible system of transport connections between Scandinavian countries and Warszawa, Krakow and Vienna as well as with Berlin, Paris and Minsk (by a railway E-20). In southern Poland, E-65 has a branch line towards Prague, Bratislava and Budapest.

According to surveys financed by Swedish railways under the management of German expert Peter W. Cardebring, turnovers between Sweden and Poland will increase up to 60 $70 \%$ by the year 2000 . Motor transport will rise by approximately the same percentage and railway transport increase will reach $47 \%$.

Project TER simultaneously requires the development of new transport branch lines connecting sea ports with Belorus, West Ukraine and the Baltic countries. The following connections should be a priority (figure 6).

(a) 'Belorussian' (Gdynia-Gdańsk-Białystok-Minsk)

(b) 'Ukrainian' (Gdynia-Gdańsk-Warszawa-Lublin-Lvov-Kiev)

(c) 'Baltic' (Gdynia-Gdańsk-Kaliningrad-Riga)

Poland's adjustment to European structures requires significant changes in the territory 


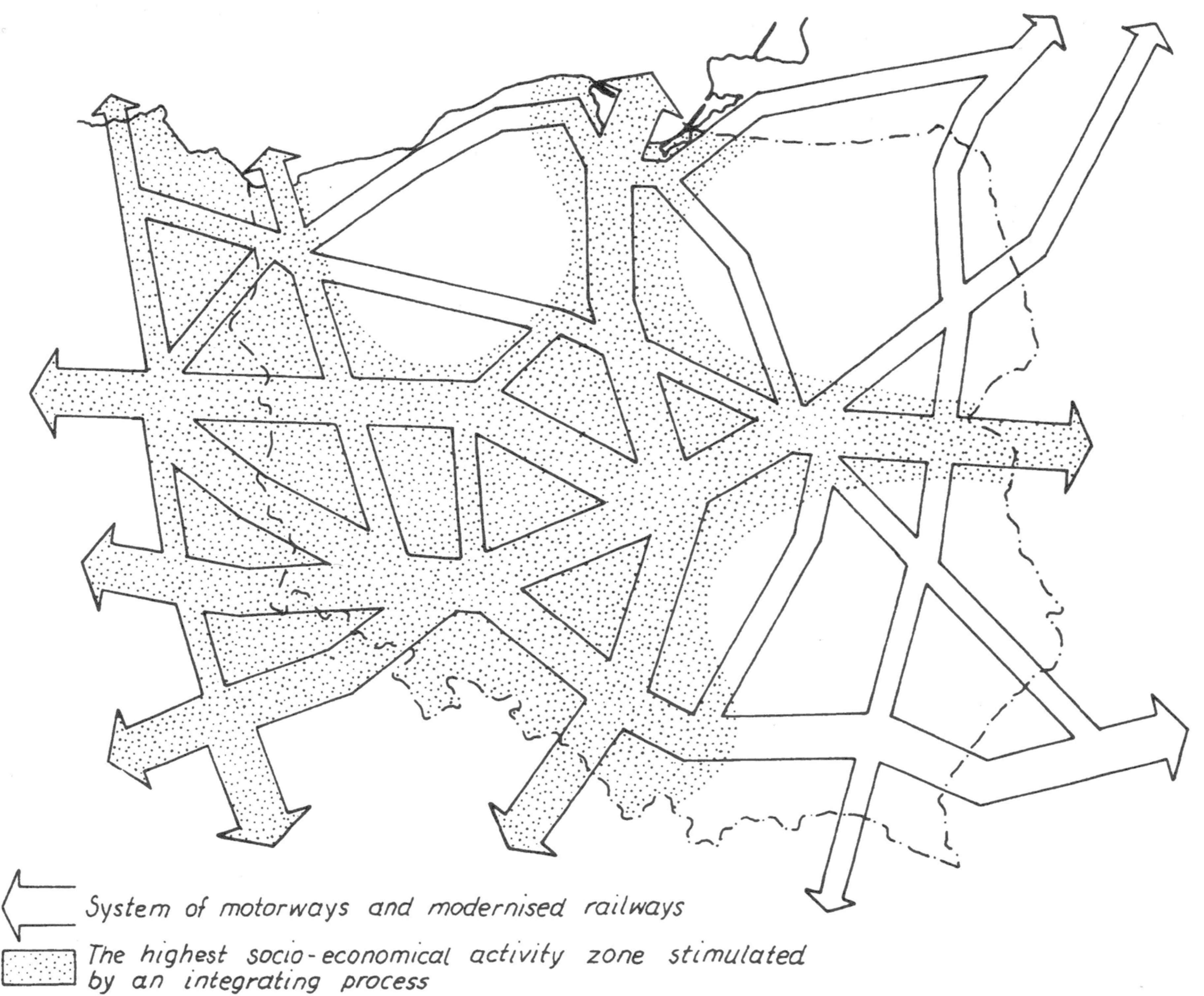

Figure 6. Hypothesis of spatial development of Poland at the turn of the 20th century. [Source: J. Kołodziejski, 1995.]

of Poland. The suggested system of motorway and modernized railway networks may evoke innovations and higher socio-economic activity, stimulated by the integrating processes.

\section{Conclusions}

The position of Polish sea ports is determined by their peripheral location with respect to main shipping routes on the Baltic and the North Sea. The development of parallel transport connections linking European transport lines in the north-south directions such as the Trans European Railway (TER), Trans European Motorway (TEM) and Pollink system (a new ferry link on the Baltic between Stockholm and the Gdańsk agglomerations) is of significant importance. Disadvantageous for Polish ports are parallel transport connections in the east-west directions which circumvent the ports and cause the loss of cargo bulk handled.

The participation of transit cargoes from the Czech Republic, Slovakia and Hungary in Polish ports' turnovers is decreasing. The cargo from these countries is taken by competitive, mainly German, ports, which are better located, and offer a wider range of services and better quality service in comparison to Polish ports. The delay in the hinterland transport development may adversely affect Polish sea ports, and this is why the development strategy of transport must take both hinterland facilities and competition into account.

The port of Gdynia is best adapted to function in intermodal chains. It has lately 
handled over $90 \%$ of total container cargoes going through all Polish ports. The Baltic Container Terminal in Gdynia is the biggest container and ro-ro terminal in Polish ports. Chances for attracting transit cargoes for Polish ports seem to lie in Belorus, northernwestern Ukraine, to some extent in Latvia and Lithuania, and in the Kaliningrad region.

The Szczecin-Swinoujście complex has to compete with the growing potential of the ports of Meklenburg such as Rostock, Mukran, Stralsund, and (built in 1993) the port of Ueckermiinde at Szczecin Bay, $30 \mathrm{~km}$ from Świnoujście. Lack of upgrading of the Odra River facilities, considering the significant participation of inland navigation in cargo handling at the port of Szczecin-Swinoujście complex, may cause a radical decrease in turnoders at these ports.

'Oresund Passage', the bridge-tunnel spanning Sund with a four-lane road as well as a double-track railway line to connect Malmo with Copenhagen, might threaten ferry shipping from Scandinavia to Świnoujście, Gdynia and Gdańsk.

\section{References}

AGC, 1985, European Agreement on Main International Railway Lines (Geneva, Switzerland).

AGTC, 1991, European Agreement on Important International Combined Transport Lines and Related Installations (Geneva, Switzerland).

BASIEwICZ, T., 1993, Studia tras szybkich kolei w Polsce [Express railway routes in Poland. Studies]. Przegląd Komunikacyjny, 199.

BURnewicz, J., 1994, Polityka transportowa [Transportation Policy]. Przeglad Komunikacyjny, 11, 12.

GrZYWACZ, W., WOJEWÓDZKA-Król, K. and RYdZKowski, W., 1994, Polityka Transportowa [Transportation Policy] (Gdańsk, Poland: Gdańsk University Press).

KOŁODZIEJSKI, J., 1995, Koncepcja polityki przestrzennego zagospodarowania kraju-Polska 2000 Plus [Concept of spatial development policy of the country-Poland 2000 Plus], Vol. II (Warsaw, Poland: Hipoteza/CUP).

KRZYŻANOWSKI, M., 1995, Drogi szybkiego ruchu na zapleczu portów polskich w świetle integracji systemów transportowych [Highways in the hinterlands of Polish ports in view of the integration of transportation systems], Czas Morza, 2(6).

1995, Ku koncepcji rozwoju przestrzennego w regionie Morza Bałtyckiego. Wizje i strategie wokół Morza Bałtyckiego 2010. [Towards the concept of spatial development in the Baltic region. Projections and strategies about the Baltic Sea 2010] (Warsaw, Poland: CUP).

misztal, K., 1994, Porty morskie w Unii Europejskiej [Sea ports in European Union] (Gdańsk, Poland: Gdańsk University Press).

SAlmonowiCz, H., 1995, Morskie porty handlowe w Szczecinie i Świnoujściu [Commercial sear ports in Szczecin-Swinoujście]. 50 lat polskiej gospodarki morskiej na Pomorzu Zachodnim, [50 years of Maritime Economy in Western Pomerania], edited by D. I. Kwinta and J. Stanielewicz (Szczecin, Poland).

STASIAK, A., (editor), 1994, Podstawowe węzły układu osadniczego Polski [Basic ties of settlement arrangements]. Biuletyn KPZK PAN z., 167.

SZCZEPANIAK, T., (editor), 1996, Transport międzynarodowy [International transport] (Warsaw, Poland).

SzWANKowski, s., 1993, Porty i ich zaplecze [Ports and facilities]. Budownictwo Okrętowe $i$ Gospodarka Morska, 3-4.

ZAleski, J., 1993, Razem czy osobno? Przyczynek do koncepcji baltyckiej wspólnoty regionalnej [Together or not? Contribution to the concept of the Baltic regional commonwealth]. CUP, Biuro Planowania Regionalnego Spopt. 